IRA-International Journal of Management \& Social Sciences

ISSN 2455-2267; Vol.13, Issue 01 (October 2018)

Pg. no. 10-22.

Institute of Research Advances

http://research-advances.org/index.php/RAJMSS

\title{
Subscribers Satisfaction on Newspaper Agency Service in Kerala
}

\author{
Dr. Sanesh C. ${ }^{1, \#} \&$ Dr. B. Johnson ${ }^{2}$ \\ ${ }^{1}$ Assistant Professor \& Head, Sri Vyasa N.S.S College, Wadakkanchery, Thrissur, Kerala, India. \\ ${ }^{2}$ Professor \& Head, Department of Commerce and Management Studies, University of Calicut, \\ Kerala, India.
}

\#corresponding author.

Type of Review: Peer Reviewed.

DOl: http://dx.doi.org/10.21013/jmss.v13.n1.p2

\begin{abstract}
How to cite this paper:
C., Sanesh, Jhonson, B. (2018). Subscribers Satisfaction on Newspaper Agency Service in Kerala. IRA-International Journal of Management \& Social Sciences (ISSN 2455-2267), 13(1), 1022. doi:http://dx.doi.org/10.21013/jmss.v13.n1.p2
\end{abstract}

(C) Institute of Research Advances.

(cc) EY-NG

This work is licensed under a Creative Commons Attribution-Non Commercial 4.0 International License subject to proper citation to the publication source of the work.

Disclaimer: The scholarly papers as reviewed and published by the Institute of Research Advances (IRA) are the views and opinions of their respective authors and are not the views or opinions of the IRA. The IRA disclaims of any harm or loss caused due to the published content to any party.

Institute of Research Advances is an institutional publisher member of Publishers International Linking Association Inc. (PILA-CrossRef), USA. The institute is an institutional signatory to the Budapest Open Access Initiative, Hungary advocating the open access of scientific and scholarly knowledge. The Institute is a registered content provider under Open Access Initiative Protocol for Metadata Harvesting (OAI-PMH).

The journal is indexed \& included in WorldCat Discovery Service (USA), CrossRef Metadata Search (USA), WorldCat (USA), OCLC (USA), Open J-Gate (India), EZB (Germany) Scilit (Switzerland), Airiti (China), Bielefeld Academic Search Engine (BASE) of Bielefeld University, Germany, PKP Index of Simon Fraser University, Canada. 


\begin{abstract}
Newspaper subscription and reading is a traditional habit among most of the people living in Kerala. Most of the people in Kerala start their daily routine by reading a newspaper with a cup of tea. Newspaper agent's service quality must be evaluated by newspaper publishers from the opinion of newspaper subscribers. If subscribers are not happy with the service of newspaper agent and delivery boys it may affect the overall prosperity of the newspaper industry itself. Therefore it is relevant to measure the service quality of newspaper agents. Nowadays readers have more options for getting information on varying issues. It revealed that regarding the distribution matters of newspapers, many of the subscribers are not pleased with the current status. Interestingly publishers are not interested to know from the subscribers regarding delivery related issues.
\end{abstract}

Key words: Timely Delivery of Newspaper, Regularity of Delivery, Neat Distribution, Prompt Billing, Prompt Cash Collection, Grievance Handling by the Newspaper Agent.

JEL: G12, G13

Paper Classification: Research Paper

\title{
Introduction
}

A newspaper is a regularly scheduled publication containing news of present events, information giving articles, different features and advertising. In the morning, most of the people have the habit of reading the newspaper along with a cup of tea. Whatever is the weather condition, whether its winter or rainy season people are expecting the newspaper to be delivered early morning throughout every day of the year. Subscribers consider it as a right to get their copy of the newspaper as soon as they get up in the early morning. If there is a delay in newspaper delivery, they will call up the newspaper agent, and will ensure that while paying their monthly newspaper subscription bill, the issue is raised up with the newspaper agent without fail. The delay in the delivery of the newspaper by newspaper delivery boys may create anxiety and frustration among most of the subscribers. It can be seen that many people will be walking restlessly waiting for the newspaper through the corridors.

\section{Statement of the problem}

The success of a newspaper distribution network entirely depends on the satisfaction of subscribers who are subscribing newspapers, even in the digital age home distribution of printed newspapers remains a key link between newspapers and its readers. The responsibility for getting the newspaper from the publisher's press into the hands of subscriber falls to the newspaper agents and delivery boy. Newspaper subscription simply means that making an arrangement with newspaper publisher for daily receipt of newspaper either in home or office and which will be delivered through the distribution network owned by newspaper agent. The price for the newspaper subscription is paid by the subscriber to the newspaper agent. Subscribers have their own views on various newspaper delivery related issues. Newspaper agent's service quality must be evaluated by newspaper publishers from the opinion of newspaper subscribers. Subscribers mainly concerned with the following factors in the newspaper distribution system. They are:-

a) Timely delivery of newspaper

b) Regularity of delivery

c) Neat distribution

d) Prompt billing

e) Prompt cash collection

f) Grievance handling

\section{Objectives of the study}

1. To understand various factors affecting subscriber satisfaction with respect to the newspaper agency service.

2. To examine the satisfaction level of subscribers with respect to the service of newspaper agents. 


\section{Hypotheses}

H0: There is no gender, income, education, location, wise significant difference in subscribers' satisfaction determining factors of newspaper agency service.

\section{Methodology and Database}

The study is descriptive in nature and is an attempt for analyzing subscriber satisfaction on newspaper distribution system prevailing in Kerala. Both primary and secondary data used for the study. Various secondary sources like books and journals, websites, research articles, theses, study report of government and professional agencies were used. Primary data have been collected by administering an interview schedule among 385 newspaper subscribers all over Kerala. Probability sampling method is used for this study. In this study, Kerala state is divided into three regions based on newspaper headquarters Kottayam, Ernakulam, and Calicut.. From this sample districts total population identified with the discussion with industrial experts and lottery method was used for sample size selection. 135 samples are identified from Kottayam and 125 each from Calicut and Ernakulam.

\section{Tools used for the study}

The tools applied for meaningful inference are One way ANOVA, Frequency analysis, Mean and Standard Deviation.

\section{Subscriber Satisfaction Determining Factors of Newspaper Agency Service}

Newspaper agents as like any other fast moving consumer goods distributors would try their level best to win the subscriber's heart and make them loyal by providing appropriate service. For assessing the quality of newspaper agency service seven variables are identified as shown below.

\section{Timely Delivery of Newspaper}

Newspapers needed to be delivered in the early morning itself. Readers have the habit of reading newspaper along with a cup of tea. Most of the subscribers may prefer to get their copy of newspaper when they are waking up in the morning. In Kerala, most of the daily newspapers are delivered between 5'0 clock to 8'0 clock. It may treat as peak time in the newspaper distribution system. Subscribers would like to get their copy of newspaper before they are moving to their workplace. Every newspaper agent tries to deliver the subscriber copy as early as possible. Subscribers may complain if newspapers are not delivered on proper time.

\section{Regularity of Delivery}

Daily newspapers needed to be delivered at subscribers' home or office each and every day early morning without any interruption. Subscribers may wait for their copy of newspaper each and every day. It is the duty of a newspaper agent to deliver the subscriber copy of newspaper without any interruption into the subscriber's home or office. The regularity of newspaper delivery is one of the important criteria for measuring service quality of newspaper agent by subscribers. At many times subscribers complained to the publisher regarding the non-delivery of the newspaper.

\section{Neat Distribution of Newspaper}

Newspapers needed to be delivered to subscriber's home or office in good condition. Newspaper delivery boys generally throw the newspaper into the corridor or lawn of the house of subscribers. In different weather conditions newspaper needed to be delivered in its proper form without any pilferage. Many times it may be a central reason for quarreling between subscribers and delivery boys because getting the newspaper in bad condition in the subscriber's hand. When analysing the quality of a newspaper agency, neat distribution of newspaper by delivery boy also became a central point. 


\section{Prompt Billing}

Subscriber's newspaper bills are generally prepared by newspaper agents. When preparing the subscriber bill, it is the duty of the agent to keep a proper register for billing and collection. There is every chance for a common amount for each month of the subscriber bill for most of the newspapers charge the same rate for their copy of the newspaper. But non-delivery of newspapers on any day, pending of the balance amount, more number of newspapers, magazine subscription, etc may make a change in the newspaper bill. Newspaper bills should be prepared with utmost care otherwise it may create unwanted problems between newspaper agent and subscriber.

\section{Prompt Cash Collection}

Agents are usually collecting the newspaper bills on a monthly basis. Each and every month newspaper agents hand over the newspaper bill to the subscriber and will collect the subscription amount from the subscriber. If any break in this collection happened, it may create arrear in the newspaper bill and may create overburden on the shoulders of subscribers. Many salaried subscribers would like to see their agent's face in the early days of the month because of getting salary on initial days of the month or final working day of every month. If newspaper agents come for collection in the late part of the month, there may be chances for nonpayment of subscription by the subscriber and they might request an extension of the payment. A comfortable subscriber always likes to pay his/her subscription charge without any delay. So it is also a quality determining factor for the newspaper agency service to collect newspaper subscription bills on proper time.

\section{Grievance Handling}

Subscribers usually complain regarding the delivery issues to the newspaper agents. Hence it is highly essential to listen and hear the subscriber and to solve the grievance of the subscriber. Newspaper agents must show their esteemed effort to solve the issue of subscribers. When grievances are raised by subscribers it should be properly handled. The approach of the newspaper agents when raising the grievance also becoming an integral part of the quality of service provided by the agent.

Following table shows the satisfaction level of subscribers regarding the above variables.

Factors Determining Subscriber Satisfaction of Newspaper Agency Business

\begin{tabular}{|c|c|c|c|c|c|c|c|c|c|c|c|c|}
\hline \multirow[t]{2}{*}{ Response } & \multicolumn{2}{|c|}{$\begin{array}{l}\text { Timely } \\
\text { delivery }\end{array}$} & \multicolumn{2}{|c|}{$\begin{array}{c}\text { Regularity of } \\
\text { delivery }\end{array}$} & \multicolumn{2}{|c|}{$\begin{array}{c}\text { Neat } \\
\text { distribution }\end{array}$} & \multicolumn{2}{|c|}{ Prompt billing } & \multicolumn{2}{|c|}{$\begin{array}{l}\text { Prompt cash } \\
\text { collection }\end{array}$} & \multicolumn{2}{|c|}{$\begin{array}{c}\text { Grievance } \\
\text { handling }\end{array}$} \\
\hline & No. & $\%$ & No. & $\%$ & No. & $\%$ & No. & $\%$ & No. & $\%$ & No. & $\%$ \\
\hline $\begin{array}{c}\text { Highly } \\
\text { dissatisfied }\end{array}$ & 39 & 10.1 & 45 & 11.7 & 53 & 13.8 & 39 & 10.1 & 45 & 11.7 & 32 & 8.3 \\
\hline Dissatisfied & 59 & 15.3 & 100 & 26.0 & 86 & 22.3 & 72 & 18.7 & 125 & 32.5 & 18 & 4.7 \\
\hline Neutral & 99 & 25.7 & 35 & 9.1 & 76 & 19.7 & 102 & 26.5 & 57 & 14.8 & 75 & 19.5 \\
\hline Satisfied & 142 & 36.9 & 161 & 41.8 & 142 & 36.9 & 132 & 34.3 & 119 & 30.9 & 204 & 53.0 \\
\hline $\begin{array}{c}\text { Highly } \\
\text { satisfied }\end{array}$ & 46 & 11.9 & 44 & 11.4 & 28 & 7.3 & 40 & 10.4 & 39 & 10.1 & 56 & 14.5 \\
\hline Total & 385 & 100.0 & 385 & 100.0 & 385 & 100. & 385 & 100 & 385 & 100 & 385 & 100. \\
\hline Mean & \multicolumn{2}{|c|}{3.2519} & \multicolumn{2}{|c|}{3.1532} & \multicolumn{2}{|c|}{3.0156} & \multicolumn{2}{|c|}{3.161} & \multicolumn{2}{|c|}{2.953} & \multicolumn{2}{|c|}{3.6078} \\
\hline S.D & \multicolumn{2}{|c|}{1.1598} & \multicolumn{2}{|c|}{1.2582} & \multicolumn{2}{|c|}{1.1988} & \multicolumn{2}{|c|}{1.1524} & \multicolumn{2}{|c|}{1.2281} & \multicolumn{2}{|c|}{1.0603} \\
\hline
\end{tabular}

Source: survey data

Above table described the subscriber satisfaction level with respect to the factors determining the quality of newspaper agency service.

- Majority of the readers [36.9 per cent] are satisfied as they are getting their copy of newspaper in proper time, followed by 25.7 per cent have a neutral stand and 10.1 per cent strongly dissatisfied. 
- Most of the subscribers are satisfied [41.8per cent] and 11.4per cent highly satisfied as they are getting their newspaper on a daily basis without any hindrances and a combined 37.7per cent dissatisfied and strongly dissatisfied regarding the regularity of delivery.

- Number of subscribers [36.9per cent] opined that they are getting their newspaper in good condition followed by 22.3per cent of readers dissatisfied the fact and 13.8 per cent strongly dissatisfied and said that distribution of a newspaper is not neat.

- Majority of the respondents [34.3per cent] admit that billing of newspaper is prompt, followed by 26.5 per cent taken a neutral stand, then 18.7 per cent dissatisfied and 10.1per cent are strongly dissatisfied that billing is prompt.

- $\quad$ Most of the respondents [53per cent] satisfied with grievance handling policy of newspaper agents and only 8.3 per cent strongly dissatisfied with grievance handling procedure of newspaper agents.

It is relevant to analyse these service qualities determining factors with the various subscriber associated variables. The independent variables selected for analysis are gender, income, education, location, number of newspaper subscribed and period of subscription of newspaper. The results of each one is presented below.

\section{Gender wise Analysis of Factors Determining Subscriber Satisfaction of Newspaper Agency Service.}

Gender is one of the important demographic variables, and it may act as a social information cue signal on different aspects. Males and females are showing a general tendency of different opinion on various aspects. Following table will show the gender wise descriptive statistics with respect to the subscriber satisfaction determining factors of newspaper agency service.

Gender Wise Analysis on Factors Determining Subscriber Satisfaction of Newspaper Agency Service

\begin{tabular}{|c|c|c|c|c|c|}
\hline Factors Determining Satisfaction & Gender & $\mathbf{N}$ & Mean & Std. Deviation & Std. Error \\
\hline \multirow{3}{*}{ Timely Delivery } & Male & 286 & 3.3147 & 1.19308 & .07055 \\
\hline & Female & 99 & 3.0707 & 1.04249 & .10477 \\
\hline & Total & 385 & 3.2519 & 1.15983 & .05911 \\
\hline \multirow{3}{*}{ Regularity of Delivery } & Male & 286 & 3.2867 & 1.25724 & .07434 \\
\hline & Female & 99 & 2.7677 & 1.18518 & .11912 \\
\hline & Total & 385 & 3.1532 & 1.25826 & .06413 \\
\hline \multirow{3}{*}{ Neat Distribution } & Male & 286 & 3.1399 & 1.20001 & .07096 \\
\hline & Female & 99 & 2.6566 & 1.12632 & .11320 \\
\hline & Total & 385 & 3.0156 & 1.19886 & .06110 \\
\hline \multirow{3}{*}{ Prompt Billing } & Male & 286 & 3.2343 & 1.20132 & .07104 \\
\hline & Female & 99 & 2.9495 & .97283 & .09777 \\
\hline & Total & 385 & 3.1610 & 1.15246 & .05873 \\
\hline \multirow{3}{*}{ Prompt cash collection } & Male & 286 & 2.9161 & 1.25094 & .07397 \\
\hline & Female & 99 & 3.0606 & 1.15898 & .11648 \\
\hline & Total & 385 & 2.9532 & 1.22810 & .06259 \\
\hline \multirow{3}{*}{ Grievance Handling } & Male & 286 & 3.6503 & 1.11927 & .06618 \\
\hline & Female & 99 & 3.4848 & .86146 & .08658 \\
\hline & Total & 385 & 3.6078 & 1.06039 & .05404 \\
\hline
\end{tabular}

Source: Survey data

When analysing factors determining subscriber satisfaction of newspaper agency service with respect to gender, it can be inferred that in most of the satisfaction determining factors male subscribers are showing the positive approach of satisfaction than female subscribers except in the case of prompt cash collection. When analysing the satisfaction level of cash collection its mean value is the lowest. When comparing mean values, women subscribers are not satisfied with the regularity of delivery (2.7677), Neat distribution (2.6566) and Prompt billing (2.9495). But in the case of prompt cash collection female subscribers are satisfied (3.0606) than dissatisfied male subscribers 
(2.9161). As per Kerala family culture, women are getting the better position in family decisions since many of the females are engaged in their job and earn income for their family. Working women are highly engaged in the routine works of their family life and in many of the cases women are waking up in the early morning than their male husband. Newspaper distribution is an early morning activity and women are directly watching the actions of newspaper agents and delivery boys. So the negative opinion of females shows some alarming situations in the newspaper distribution system prevailing in Kerala.

Hypotheses Testing of Gender Wise Difference on Factors Determining Subscriber Satisfaction of Newspaper Agency Service.

H0: There is no gender wise significant difference in factors determining subscriber satisfaction of newspaper agency service.

H1: There is gender wise significant difference in factors determining subscriber satisfaction of newspaper agency service.

ANOVA on Gender Wise Difference on Factors Determining Subscriber Satisfaction of Newspaper Agency Service

\begin{tabular}{|l|c|c|c|c|c|}
\hline \multicolumn{1}{|c|}{$\begin{array}{c}\text { Factors Determining } \\
\text { Satisfaction }\end{array}$} & $\begin{array}{c}\text { Sum of } \\
\text { Squares }\end{array}$ & $\begin{array}{c}\text { Degree of } \\
\text { Freedom }\end{array}$ & $\begin{array}{c}\text { Mean sum of } \\
\text { squares }\end{array}$ & $\begin{array}{c}\text { F } \\
\text { value }\end{array}$ & value \\
\hline Timely delivery & 4.378 & 1 & 4.378 & 3.274 & $.071^{*}$ \\
\hline Regularity of delivery & 19.812 & 1 & 19.812 & 12.902 & $.000^{*}$ \\
\hline Neat distribution & 17.178 & 1 & 17.178 & 12.304 & $.001^{*}$ \\
\hline Prompt billing & 5.964 & 1 & 5.964 & 4.532 & $.034^{*}$ \\
\hline Prompt cash collection & 1.536 & 1 & 1.536 & 1.019 & $.314^{*}$ \\
\hline Grievance handling & 2.014 & 1 & 2.014 & 1.795 & $.181 *$ \\
\hline
\end{tabular}

Source: Survey data

\section{*Significant at 5\% level of significance}

The result of the analysis clearly shows that $\mathrm{p}$ values of regularity of delivery, neat distribution and prompt billing is less than.05 and the null hypotheses is rejected at 5\% significance level which gives implication that there is significant difference in the opinions of gender in regularity of delivery ( $\mathrm{p}$ value $=0.000)$, neat distribution $(0.001)$ and prompt billing (0.034). $\mathrm{P}$ values of timely delivery, prompt cash collection and grievance handling is greater than.05 and it can be inferred that there is no significant difference in the opinions of timely delivery (0.071), prompt cash collection (0.314), and grievance handling (0.181), based on gender.

\section{Income wise Analysis of Factors Determining Subscriber Satisfaction of Newspaper Agency Service}

Income of a person determines the purchasing and spending capacity of the person. In the earlier days subscription of a newspaper treated as a luxury expense but nowadays newspaper subscription is treated as a necessity good purchase. It will be ideal to understand how the income of subscriber differentiates subscriber satisfaction determining factors of newspaper agency service. 
IRA-International Journal of Management E' Social Sciences

Income wise Analysis of Factors Determining Subscriber Satisfaction of Newspaper Agency Service

\begin{tabular}{|c|c|c|c|c|c|}
\hline $\begin{array}{l}\text { Factors determining } \\
\text { satisfaction }\end{array}$ & $\begin{array}{c}\text { Annual Income } \\
\text { (RS.) }\end{array}$ & $\mathbf{N}$ & Mean & Std. Deviation & Std. Error \\
\hline \multirow{4}{*}{ Timely Delivery } & Below 200000 & 191 & 3.3455 & 1.09831 & .07947 \\
\hline & $200000-500000$ & 170 & 3.2294 & 1.26877 & .09731 \\
\hline & $500000-1000000$ & 24 & 2.6667 & .48154 & .09829 \\
\hline & Total & 385 & 3.2519 & 1.15983 & .05911 \\
\hline \multirow{4}{*}{ Regularity of Delivery } & Below 200000 & 191 & 3.2513 & 1.19635 & .08656 \\
\hline & $200000-500000$ & 170 & 2.9824 & 1.34768 & .10336 \\
\hline & $500000-1000000$ & 24 & 3.5833 & .88055 & .17974 \\
\hline & Total & 385 & 3.1532 & 1.25826 & .06413 \\
\hline \multirow{4}{*}{ Neat Distribution } & Below 200000 & 191 & 3.0785 & 1.15125 & .08330 \\
\hline & $200000-500000$ & 170 & 2.8471 & 1.26870 & .09731 \\
\hline & $500000-1000000$ & 24 & 3.7083 & .69025 & .14090 \\
\hline & Total & 385 & 3.0156 & 1.19886 & .06110 \\
\hline \multirow{4}{*}{ Prompt Billing } & Below 200000 & 191 & 3.3770 & 1.06341 & .07695 \\
\hline & $200000-500000$ & 170 & 3.0235 & 1.23534 & .09475 \\
\hline & $500000-1000000$ & 24 & 2.4167 & .71728 & .14641 \\
\hline & Total & 385 & 3.1610 & 1.15246 & .05873 \\
\hline \multirow{4}{*}{ Prompt cash collection } & Below 200000 & 191 & 3.0262 & 1.17175 & .08478 \\
\hline & $200000-500000$ & 170 & 2.8529 & 1.30389 & .10000 \\
\hline & $500000-1000000$ & 24 & 3.0833 & 1.10007 & .22455 \\
\hline & Total & 385 & 2.9532 & 1.22810 & .06259 \\
\hline \multirow{4}{*}{ Grievance Handling } & Below 200000 & 191 & 3.6178 & .81143 & .05871 \\
\hline & $200000-500000$ & 170 & 3.5706 & 1.31818 & .10110 \\
\hline & $500000-1000000$ & 24 & 3.7917 & .72106 & .14719 \\
\hline & Total & 385 & 3.6078 & 1.06039 & .05404 \\
\hline
\end{tabular}

Source: Survey data 
It is clear that different income group thinks differently on satisfaction determining factors. For the analysis purpose annual income of the subscribers categorized as low-income people (below 200000), Middle-income people (200000-500000), and upper-income group (500000-1000000). From the descriptive analysis, it is clear that lowincome subscribers satisfied with all satisfaction determining factors as the total mean of all individual factors are high. But some differences in the opinions of middle and upper income can be seen on selected factors. Middleincome subscribers are not satisfied with respect to the regularity of delivery (2.9824), neat distribution (2.8471), and prompt cash collection (2.8529). Upper-income classes have a different opinion on timely delivery (2.6667) and prompt billing (2.4167). When looking the totality of mean factor wise except for prompt cash collection (2.9532) remaining all factors are satisfied in general.

\section{Hypotheses Testing of Income wise Difference on Factors Determining Subscriber Satisfaction of Newspaper Agency Service}

H0: There is no income wise significant difference in Subscribers' opinion on factors determining satisfaction of newspaper agency service.

H1: There is income wise significant difference in Subscribers' opinion on factors determining satisfaction of newspaper agency service.

ANOVA on Income Wise Difference on Factors Determining Subscriber Satisfaction of Newspaper Agency Service

\begin{tabular}{|l|c|c|c|c|c|}
\hline $\begin{array}{c}\text { Factors determining } \\
\text { Satisfaction }\end{array}$ & $\begin{array}{c}\text { Sum of } \\
\text { Squares }\end{array}$ & $\begin{array}{c}\text { Degree of } \\
\text { Freedom }\end{array}$ & $\begin{array}{c}\text { Mean sum of } \\
\text { squares }\end{array}$ & F value & P value \\
\hline Timely delivery & 9.981 & 2 & 4.991 & 3.763 & $.024^{*}$ \\
\hline Regularity of delivery & 11.241 & 2 & 5.620 & 3.598 & $.028^{*}$ \\
\hline Neat distribution & 17.103 & 2 & 8.551 & 6.108 & $.002^{*}$ \\
\hline Prompt billing & 25.418 & 2 & 12.709 & 10.018 & $.000^{*}$ \\
\hline Prompt cash collection & 3.132 & 2 & 1.566 & 1.039 & $.355^{*}$ \\
\hline Grievance handling & 1.066 & 2 & .533 & .473 & $.624^{*}$ \\
\hline
\end{tabular}

Source: Survey data

*Significant at $5 \%$ level of significance

The above table gives details of the ANOVA on income wise difference on factors determining subscriber satisfaction of newspaper agency service. It is clear that $\mathrm{p}$ values of timely delivery (.024), regularity of delivery (.028), neat distribution (.002) and prompt billing is less than .05 and the null hypothesis is rejected at 5\% significance level and hence there is an income wise significant difference in subscriber's opinion on the factors of satisfaction determining newspaper agency service. Regarding prompt cash collection (0.355) and grievance handling (0.624), the p-value is greater than .05 and the null hypotheses are accepted at $5 \%$ significance level and hence there is no income wise significant difference in subscriber's opinion on these factors determining satisfaction on newspaper agency service.

\section{Education wise Analysis of Factors Determining Subscriber Satisfaction of Newspaper Agency Service}

The State of Kerala considered being one of the highly literate states in the country. People living in Kerala give foremost importance to educational activities. Newspapers are highly penetrated in Kerala. In order to understand whether the difference in the education of subscribers creates any impact in subscriber satisfaction determining factors of newspaper agency service, following analysis has been made. 
IRA-International Journal of Management E' Social Sciences

Education Wise Analysis of Factors Determining Subscriber Satisfaction of Newspaper Agency Service

\begin{tabular}{|c|c|c|c|c|c|}
\hline $\begin{array}{l}\text { Factors determining } \\
\text { Satisfaction }\end{array}$ & Education & $\mathbf{N}$ & Mean & Std. Deviation & Std. Error \\
\hline \multirow{6}{*}{ Timely Delivery } & Below 7 standard & 24 & 2.6667 & .48154 & .09829 \\
\hline & 7STD-SSLC & 130 & 3.0769 & 1.32135 & .11589 \\
\hline & SSLC-PDC/+2 & 104 & 3.0673 & 1.24061 & .12165 \\
\hline & PDC/+2-Graduation & 113 & 3.8230 & .77032 & .07247 \\
\hline & PG and above & 14 & 2.6429 & .49725 & .13289 \\
\hline & Total & 385 & 3.2519 & 1.15983 & .05911 \\
\hline \multirow{6}{*}{ Regularity of Delivery } & Below 7 standard & 24 & 3.5833 & .88055 & .17974 \\
\hline & 7STD-SSLC & 130 & 2.9769 & 1.26040 & .11054 \\
\hline & SSLC-PDC/+2 & 104 & 3.1827 & 1.32023 & .12946 \\
\hline & PDC/+2-Graduation & 113 & 3.3451 & 1.20097 & .11298 \\
\hline & PG and above & 14 & 2.2857 & 1.26665 & .33853 \\
\hline & Total & 385 & 3.1532 & 1.25826 & .06413 \\
\hline \multirow{6}{*}{ Neat Distribution } & Below 7 standard & 24 & 3.7083 & .69025 & .14090 \\
\hline & 7STD-SSLC & 130 & 2.8462 & 1.28474 & .11268 \\
\hline & SSLC-PDC/+2 & 104 & 2.9615 & 1.11410 & .10925 \\
\hline & PDC/+2-Graduation & 113 & 3.2035 & 1.20386 & .11325 \\
\hline & PG and above & 14 & 2.2857 & .91387 & .24424 \\
\hline & Total & 385 & 3.0156 & 1.19886 & .06110 \\
\hline \multirow{6}{*}{ Prompt Billing } & Below 7 standard & 24 & 2.4167 & .71728 & .14641 \\
\hline & 7STD-SSLC & 130 & 3.1923 & 1.18188 & .10366 \\
\hline & SSLC-PDC/+2 & 104 & 3.2885 & 1.16313 & .11405 \\
\hline & PDC/+2-Graduation & 113 & 3.2566 & 1.14781 & .10798 \\
\hline & PG and above & 14 & 2.4286 & .75593 & .20203 \\
\hline & Total & 385 & 3.1610 & 1.15246 & .05873 \\
\hline \multirow{6}{*}{ Prompt Cash Collection } & Below 7 standard & 24 & 3.0833 & 1.10007 & .22455 \\
\hline & 7STD-SSLC & 130 & 2.6923 & 1.16703 & .10236 \\
\hline & SSLC-PDC/+2 & 104 & 3.0288 & 1.21045 & .11869 \\
\hline & PDC/+2-Graduation & 113 & 3.1947 & 1.31515 & .12372 \\
\hline & PG and above & 14 & 2.6429 & 1.00821 & .26945 \\
\hline & Total & 385 & 2.9532 & 1.22810 & .06259 \\
\hline Grievance Handling & Below 7 standard & 24 & 3.7917 & .72106 & .14719 \\
\hline
\end{tabular}


IRA-International Journal of Management E' Social Sciences

\begin{tabular}{|c|c|c|c|c|c|}
\hline $\begin{array}{c}\text { Factors determining } \\
\text { Satisfaction }\end{array}$ & Education & $\mathbf{N}$ & Mean & Std. Deviation & Std. Error \\
\hline & 7STD-SSLC & 130 & 3.3923 & 1.32065 & .11583 \\
\hline & SSLC-PDC/+2 & 104 & 3.5385 & .89142 & .08741 \\
\hline & PDC/+2-Graduation & 113 & 3.9735 & .85000 & .07996 \\
\hline & PG and above & 14 & 2.8571 & .36314 & .09705 \\
\hline & Total & 385 & 3.6078 & 1.06039 & .05404 \\
\hline
\end{tabular}

Source: Survey data

It can be inferred from the above table that education wise analysis of subscriber's opinion was different in many aspects. It can be seen that highly educated peoples (PG and above) dissatisfied with all variables determining subscriber satisfaction. While considering the rest of the group of education of subscribers, low educated subscribers (below 7 standard) were not satisfied with billing and timely delivery of the newspaper. Newspapers were not delivered in proper form was the opinion of SSLC/PDC qualified subscribers opinion in addition to the opinion of postgraduates. As per the total mean analysis of variables except for prompt cash collection (2.9532) all other variables are satisfied by the subscribers which determine service quality of newspaper agency.

\section{Hypotheses Testing of Education wise Difference on Factors Determining Subscriber Satisfaction of Newspaper Agency Service}

H0: There is no education wise significant difference in factors determining subscriber satisfaction of newspaper agency service

H1: There is an education wise significant difference in factors determining subscriber satisfaction of newspaper agency service

\section{ANOVA on Education wise Difference on Factors Determining Subscriber Satisfaction of Newspaper Agency} Service

\begin{tabular}{|l|c|c|c|c|c|}
\hline \multicolumn{1}{|c|}{$\begin{array}{c}\text { Factors determining } \\
\text { satisfaction }\end{array}$} & $\begin{array}{c}\text { Sum of } \\
\text { Squares }\end{array}$ & $\begin{array}{c}\text { Degree of } \\
\text { Freedom }\end{array}$ & $\begin{array}{c}\text { Mean sum of } \\
\text { squares }\end{array}$ & F value & P value \\
\hline Timely delivery & 57.794 & 4 & 14.448 & 11.968 & $.000^{*}$ \\
\hline Regularity of delivery & 23.269 & 4 & 5.817 & 3.781 & $.005 *$ \\
\hline Neat distribution & 27.003 & 4 & 6.751 & 4.887 & $.001 *$ \\
\hline Prompt billing & 23.658 & 4 & 5.914 & 4.621 & $.001 *$ \\
\hline Prompt cash collection & 17.788 & 4 & 4.447 & 3.010 & $.018 *$ \\
\hline Grievance handling & 30.345 & 4 & 7.586 & 7.181 & $.000 *$ \\
\hline
\end{tabular}

Source: Survey data

*Significant at $5 \%$ level of significance

The above ANOVA table gives the result of education wise differences on factors determining subscriber satisfaction of newspaper agency service. The $\mathrm{P}$ value of all the factors is less than 0.05 and the null hypothesis is rejected, meaning that there is an education wise significant difference in factors determining subscriber's satisfaction of newspaper agency service. 


\section{Location wise Analysis of Factors Determining Subscriber Satisfaction of Newspaper Agency Service}

Location of subscribers is considered to be one of the important elements for efficient distribution of newspapers in Kerala. Kerala is a small state located in the south-west corner of India. It represents only 1.22 percentage of the total area of India but has $2.84 \%$ of the total population of the country. As per geographical classification, Kerala can be divided into three. They are rural, urban and semi urban. Moreover, rapid urbanisation from rural land is happening in Kerala. The impact of location wise analysis of factors determining subscriber satisfaction of newspaper agency service is presented below.

Location Wise Analysis of Factors Determining Subscriber Satisfaction of Newspaper Agency Service

\begin{tabular}{|c|c|c|c|c|c|}
\hline $\begin{array}{c}\text { Factors determining } \\
\text { satisfaction }\end{array}$ & Locality & $\mathbf{N}$ & Mean & Std. Deviation & Std. Error \\
\hline \multirow{4}{*}{ Timely Delivery } & Rural & 137 & 3.3577 & 1.27035 & .10853 \\
\hline & Urban & 165 & 3.1818 & 1.09474 & .08523 \\
\hline & Semi urban & 83 & 3.2169 & 1.09375 & .12006 \\
\hline & Total & 385 & 3.2519 & 1.15983 & .05911 \\
\hline \multirow{4}{*}{ Regularity of Delivery } & Rural & 137 & 3.1533 & 1.32782 & .11344 \\
\hline & Urban & 165 & 3.0970 & 1.24560 & .09697 \\
\hline & Semi urban & 83 & 3.2651 & 1.16958 & .12838 \\
\hline & Total & 385 & 3.1532 & 1.25826 & .06413 \\
\hline \multirow{4}{*}{ Neat Distribution } & Rural & 137 & 3.1971 & 1.26514 & .10809 \\
\hline & Urban & 165 & 2.9515 & 1.20874 & .09410 \\
\hline & Semi urban & 83 & 2.8434 & 1.02982 & .11304 \\
\hline & Total & 385 & 3.0156 & 1.19886 & .06110 \\
\hline \multirow{4}{*}{ Prompt Billing } & Rural & 137 & 3.0949 & 1.25372 & .10711 \\
\hline & Urban & 165 & 3.1515 & 1.14021 & .08877 \\
\hline & Semi urban & 83 & 3.2892 & .99425 & .10913 \\
\hline & Total & 385 & 3.1610 & 1.15246 & .05873 \\
\hline \multirow{4}{*}{ Prompt cash collection } & Rural & 137 & 3.0803 & 1.29512 & .11065 \\
\hline & Urban & 165 & 2.9576 & 1.16531 & .09072 \\
\hline & Semi urban & 83 & 2.7349 & 1.22060 & .13398 \\
\hline & Total & 385 & 2.9532 & 1.22810 & .06259 \\
\hline \multirow{4}{*}{ Grievance Handling } & Rural & 137 & 3.7007 & 1.08034 & .09230 \\
\hline & Urban & 165 & 3.5333 & 1.05653 & .08225 \\
\hline & Semi urban & 83 & 3.6024 & 1.03523 & .11363 \\
\hline & Total & 385 & 3.6078 & 1.06039 & .05404 \\
\hline
\end{tabular}

Source: Survey data

From the location wise analysis of subscriber satisfaction determining factors of newspaper agency service, it is clear that rural subscribers are satisfied with all the factors which determine the quality of newspaper agency service. Both urban and semi-urban customers are not satisfied with cash collection factor and neat distribution of newspapers since their mean values are 2.9532 and 3.0156.

Hypotheses Testing of Location Wise Difference on Factors Determining Subscriber Satisfaction of Newspaper Agency Service

H0: There is no location wise significant difference on factors determining subscriber satisfaction of newspaper agency service.

$\mathrm{H} 1$ : There is location wise significant difference on factors determining subscriber satisfaction of newspaper agency service. 
IRA-International Journal of Management छ' Social Sciences

ANOVA on Location wise Difference on Factors Determining Subscriber Satisfaction of Newspaper Agency Service

\begin{tabular}{|c|c|c|c|c|c|}
\hline $\begin{array}{c}\text { Factors determining } \\
\text { satisfaction }\end{array}$ & $\begin{array}{c}\text { Sum of } \\
\text { Squares }\end{array}$ & $\begin{array}{c}\text { Degree of } \\
\text { Freedom }\end{array}$ & $\begin{array}{c}\text { Mean sum of } \\
\text { squares }\end{array}$ & $\begin{array}{c}\text { F } \\
\text { value }\end{array}$ & $\begin{array}{c}\text { P } \\
\text { value }\end{array}$ \\
\hline Timely delivery & 2.445 & 2 & 1.222 & .908 & $.404^{*}$ \\
\hline Regularity of delivery & 1.560 & 2 & .780 & .491 & $.612^{*}$ \\
\hline Neat distribution & 7.652 & 2 & 3.826 & 2.685 & $.069^{*}$ \\
\hline Prompt billing & 1.977 & 2 & .988 & .743 & $.476^{*}$ \\
\hline Prompt cash collection & 6.170 & 2 & 3.085 & 2.057 & $.129^{*}$ \\
\hline Grievance handling & 2.101 & 2 & 1.050 & .934 & $.394^{*}$ \\
\hline
\end{tabular}

Source: Survey data

* Significant at 5\% level of significance

The above ANOVA table gives the result of location wise difference on subscriber satisfaction determining factors of newspaper agency service. The $\mathrm{P}$ value of all the factors is more than 0.05 and the null hypothesis is accepted meaning that there is no location wise significant difference in factors determining subscriber satisfaction of newspaper agency service.

\section{Findings of the study}

1. Majority of the subscribers are satisfied with the timely delivery of newspapers, regularity of delivery, grievance handling of subscriber issues, neat delivery by delivery boys and they are moderately satisfied with the cash bill collection from subscribers that means many newspaper agents are not collecting their newspaper cash bill from subscribers on a regular basis.

2. In most of the satisfaction determining factors, male subscribers have shown the positive approach of satisfaction than female subscribers except in the case of prompt cash collection.

3. Income wise analysis of subscriber satisfaction determining factors of newspaper agency service shows that low-income people subscribers are satisfied with all satisfaction determining factors as like the total mean of all individual factors.

4. Education wise analysis of subscriber's opinion about newspaper agency service was different in many aspects. It can be seen that highly educated people are (PG and above) dissatisfied with all variables determining subscriber satisfaction. While considering rest in the group of education of subscribers, low educated subscribers (below 7 standard) are not satisfied with billing and timely delivery of the newspaper. Newspapers were not delivered in proper form is the opinion of SSLC/PDC qualified subscribers, in addition to the opinion of postgraduates.

5. From the location wise analysis of subscriber satisfaction determining factors of newspaper agency service, it is clear that rural subscribers are satisfied with all the factors which determine the quality of newspaper agency service. Both urban and semi-urban customers are not satisfied with cash collection factor and neat distribution of newspapers.

\section{Conclusion}

In this research article various aspects of the newspaper subscription, from the viewpoint of newspaper subscriber had been measured under different heads. The opinion of delivery related issues and newspaper agents' service are closely evaluated using appropriate statistical tools. Newspaper subscribers are providing bread and butter to the 
publishers, newspaper agents and delivery boys. Therefore satisfaction of newspaper subscriber is to be ensured for the successful operation of the newspaper industry.

\section{References}

[1]. Harikrishnan, S.M. (2011), 'A business model for a customized newspaper in tune with current consumer market', PhD thesis, Department of Management Studies, Kannur University.

[2]. Lisa George and Joel Waldfogel. Who Affects Whom in Daily Newspaper Markets? Journal of Political Economy. University of Chicago Press. 111(4): 765-784. August 2003.

[3]. Pillai, M. (1993). 'Management of Newspaper Industry in Kerala with Special Reference to Marketing'. Ph.D Thesis, CUSAT, Kochi

[4]. Chaundri V., 1998, Pricing and Efficiency in a Circulation Industry: The Case of Newspapers, Information Economics and Policy, 10: 59-76.

[5]. C. Gopinath (2009), The Hindu Business Line, Newspapers struggle to find a new business model, Chennai Edition, Monday, May 25, p. 11.

[6]. Ito, R. (1966), 'Effects of A Newspaper Strike on Retail Sales', Journal of Marketing, Vol. 30, No. 3 (Jul., 1966), pp. $54-58$

[7]. Jeffrey, R. (1987),' Culture of Daily Newspapers in India-How It is Grown, What it Means', Economic and Political Weekly y, Vol. 28, No. 38 (Sep. 18, 1987), pp. 2004. 